\title{
Are Patagonia grasslands being overgrazed? A response to Marino et al. (2020)
}

\author{
Gabriel Oliva $^{1,2}$ (1) | Paula Paredes ${ }^{1,2}$ | Daniela Ferrante ${ }^{1,2}$ | Carla Cepeda ${ }^{1}$ | \\ Jorge Rabinovich ${ }^{3,4}$
}

${ }^{1}$ Estación Experimental Agropecuaria (EEA), INTA, Río Gallegos, Santa Cruz, Argentina

${ }^{2}$ Unidad Académica Río Gallegos, Universidad Nacional de la Patagonia Austral, Río Gallegos, Santa Cruz, Argentina

${ }^{3}$ Consejo Nacional de Investigaciones Científicas y Técnicas, Buenos Aires, Argentina

${ }^{4}$ CEPAVE, Universidad Nacional de La Plata, La Plata, Argentina

Correspondence

Gabriel Oliva

Email: oliva.gabriel@inta.gob.ar

Funding information

Instituto Nacional de Tecnología

Agropecuaria, Grant/Award Number:

2019-PD-E2-1038-002

Handling Editor: Philip Stephens

\section{Abstract}

1. Based upon primary productivity estimates, Oliva et al. (2019) concluded that, at the end of last century and after long periods of overgrazing, Patagonia's domestic stocks adjusted to regional-scale herbivore carrying capacity. Populations of guanaco, a native camelid, increased thereafter, driving combined grazing pressures once again over carrying capacity in some areas.

2. Marino et al. (2020) argued that grazing is not really at equilibrium because domestic stocks are concentrated in areas that remain overgrazed. They support the ideas that guanaco density is auto-regulated by resource-defence territoriality, and that guanacos are weak competitors with domestic stock, occupying only marginal areas. In their view, Oliva et al. (2019) put guanacos in the role of scapegoats, leaving domestic stocks unchecked.

3. Equilibrium at regional scale does not preclude overgrazing and under-grazing at local scales. By separating areas with and without domestic stocks, Marino et al. (2020) estimated overgrazing at $28 \%$ in Chubut Province and $73 \%$ in Santa Cruz Province. Our recalculations show $28 \%$ and $47 \%$ domestic overgrazing, respectively. However, when combined with guanaco densities, these increase to $48 \%$ for Chubut and $108 \%$ for Santa Cruz.

4. We question the hypothesised lack of competitive value and efficient self-regulating mechanisms that would prevent guanaco populations from overshooting carrying capacity. A dataset of 13 sheep farms showed mean density of $26 \pm 3.8$ guanacos $/ \mathrm{km}^{2}$ and high combined grazing pressures. This was also observed in a protected area of Chubut that reached 42 guanacos $/ \mathrm{km}^{2}$ and crashed during drought, with $60 \%$ mortality. Thereafter, guanacos increased to 70 guanacos/ $\mathrm{km}^{2}$, with recruitment rates that showed a complex response of density dependence but remained relatively elevated at densities above the estimated carrying capacity.

5. Synthesis and applications. Marino et al. (2020) are right to question the apparent equilibrium of domestic stocks that are concentrated in areas that may be still overgrazed. But ground data show that guanaco populations have inefficient density population regulation and can reach densities well over carrying capacity, even in the presence of sheep. This does not mean that the main control should be on growing guanaco populations but it stresses our conclusion that 
joint management of the native-domestic herbivore system is urgently needed. Joint management can be effected through local plans, as current guanaco management permits can only be issued in areas that are not overgrazed by sheep. Farm management plans may in this way transform an apparent competitor into a valuable resource, complementary to sheep raising.

\section{KEYWORDS}

domestic-wildlife spatial segregation, guanacos, herbivore carrying capacity, herbivore competition, rangeland management, satellite primary productivity, wildlife population regulation

\section{1 | INTRODUCTION}

Management of guanacos, a large native wild camelid herbivore of South America, is a controversial issue. Guanaco populations decreased over the past century but recovered in the past two decades, coincident with sheep de-stocking in a context of reduced predation, hunting bans and milder winters. By 2015, guanacos posed a problem of potential competition in some remaining sheep farms in southern Patagonia (Hernández, Corcorán, Graells, Roos, \& Downey, 2017). The species was included in CITES Appendix II in 1996, and conservation concerns at that time explain why the first Argentine National Management Plan (Baldi et al., 2006) did not incorporate population control management. However, in the last decade, some provincial management plans authorised potential population control through hunting or culling. In the current National Guanaco Management Plan, updated in 2019, commercial hunting was allowed within local management plans (SAyDS, 2019). This prompted a debate: are wild populations of guanaco in extensive domestic production systems degrading the land and competing with domestic stock? Should they be managed and kept below carrying capacity of the land, or should they be left to reach an eventual equilibrium? To inform this debate, Oliva, Paredes, Ferrante, Cepeda, and Rabinovich (2019) estimated total herbivore carrying capacity of the Patagonia region. In that paper, we concluded that domestic stock-introduced at the end of the 19th century-must have reached (and then exceeded) regional herbivore carrying capacity in the 1930s, and then overgrazed for several decades. From 1980 on, sheep stocks fell sharply and were not completely replaced by growing cattle numbers; at a regional scale, total domestic herbivore pressure reached some degree of equilibrium with forage production in 1990 , remaining so to present times. Since 2000 , guanaco populations have increased and, in some areas, as a result, the combined grazing pressure is once again above carrying capacity.

Marino, Rodriguez, and Schroeder (2020) have disputed some of the conclusions of Oliva et al. (2019), arguing that grazing is not at equilibrium because domestic stock has been withdrawn from some less-productive or degraded areas and concentrated in others. They claim that guanaco populations are self-regulated by behavioural mechanisms, that they are competitively inferior to sheep and consume low-quality forage when in mixed systems. As a result of their greater tolerance of degraded areas, their increase has been in this way concentrated in marginal areas that are not heavily exploited by sheep. Their conclusion is that guanacos should not be made scapegoats that take the blame for land degradation: management efforts concentrated upon native populations would put them at risk, while domestic stocks, the supposed real cause of ongoing degradation, would remain unchecked. Here, we re-evaluate our original data and present new evidence to contest these claims.

\section{ARE DOMESTIC STOCK NUMBERS AT EQUILIBRIUM WITH CARRYING CAPACITY?}

The main argument of Marino et al. (2020) is that grazing is not at equilibrium because domestic stocks have been withdrawn or lost in large areas of Patagonia, with the remaining animals concentrated and overgrazing still-productive land. We agree with this view, but we consider that it does not contradict our previous conclusions because the historic trend of domestic stocks to adjust to carrying capacity at a regional (and even provincial) scale in the last century shown by hard data in Oliva et al. (2019) does not preclude the existence of overgrazing and under-grazing at smaller (local) scales. Marino et al. (2020) estimated that land that remains dedicated to sheep production would have $73 \%$ and $28 \%$ overgrazing in Santa Cruz and Chubut Provinces, respectively. It is true that both areas are overgrazed, although a recalculation using more precise province $\times$ biozone carrying capacity data, based upon the MOD17A3 methodology, shows $47 \%$ overgrazing in Santa Cruz, over one-third lower than the estimate of Marino et al. (2020; Table 1). In the case of Chubut, our recalculations accord with those of Marino et al. (2020). However, overgrazing estimates should also include guanaco populations, as native fauna is not restricted to areas where sheep production has been abandoned. To estimate guanaco densities in areas with and without grazing we proceeded as follows: we assigned to each Biozone of the Provinces of Chubut and Santa Cruz a guanaco population value as estimated by Bay Gavuzzo et al. (2015; Table 2); as these authors did not provide estimates for the Dry and Humid 
TAB LE 1 Recalculation of table 1 of Marino et al. (2020) using MOD17A3 images and tabulated separately for areas with and without domestic grazing. Carrying capacity, domestic stock and guanaco populations are expressed in animal units (AU). Overgrazing was calculated as ((Herbivore stock - Carrying capacity)/Carrying capacity $\times 100)$. Guanaco population values from provincial population estimations (Bay Gavuzzo et al., 2015) distributed in relation to the relative densities reported for biozones in this study. As the main sheep-abandoned areas are mostly in the Central District, all abandoned areas were assigned the guanaco density of the Central District. Dry and Humid Magellan Steppe biozones in Santa Cruz were assigned densities reported in Manero et al. (2013) interpolated to adjust for differences in the provincial estimates reported between these two studies. Positive overgrazing values indicate herbivore excess over carrying capacity; negative overgrazing values indicate that herbivore densities are below carrying capacity. The column 'Domestic overgrazing (\%)' has a value in brackets that shows the corresponding domestic overgrazing estimation of Marino et al. (2020)

\begin{tabular}{|c|c|c|c|c|c|c|c|c|c|}
\hline & & $\begin{array}{l}\text { Area } \\
\left(\mathrm{km}^{2}\right)\end{array}$ & $\begin{array}{l}\text { Cons. forage } \\
\left(\mathrm{kg} \mathrm{DM} \mathrm{ha}^{-1}\right. \\
\left.\text { year }^{-1}\right)\end{array}$ & $\begin{array}{l}\text { Herbivore } \\
\text { carrying } \\
\text { capacity } 2015 \\
\text { (AU) }\end{array}$ & $\begin{array}{l}\text { Domestic } \\
\text { stock } 2015 \\
(\mathrm{AU})\end{array}$ & $\begin{array}{l}\text { Domestic } \\
\text { overgrazing } \\
(\%)\end{array}$ & $\begin{array}{l}\text { Guanaco } \\
\text { (AU) }\end{array}$ & $\begin{array}{l}\text { Guanaco } \\
\text { and } \\
\text { domestic } \\
\text { (AU) }\end{array}$ & $\begin{array}{l}\text { Domestic } \\
\text { and guanaco } \\
\text { overgrazing } \\
\text { (\%) }\end{array}$ \\
\hline \multirow[t]{3}{*}{$\begin{array}{r}\text { Santa } \\
\text { Cruz }\end{array}$} & $\begin{array}{l}\text { With } \\
\text { livestock }\end{array}$ & 119,873 & 85 & 306,025 & 448,620 & 47 [73] & 181,055 & 629,675 & 106 \\
\hline & $\begin{array}{l}\text { Without } \\
\text { livestock }\end{array}$ & 102,764 & 55 & 168,312 & 0 & & 137,495 & 137,495 & -18 \\
\hline & Total & 222,637 & 78 & 474,000 & 448,620 & -5 & 318,550 & 767,170 & 62 \\
\hline \multirow[t]{2}{*}{ Chubut } & $\begin{array}{l}\text { With } \\
\text { livestock }\end{array}$ & 179,913 & 108 & 580,911 & 744,210 & 28 [28] & 120,134 & 864,344 & 49 \\
\hline & $\begin{array}{l}\text { Without } \\
\text { livestock }\end{array}$ & 29,297 & 72 & 63,085 & 0 & & 9,366 & 9,366 & -85 \\
\hline
\end{tabular}

TAB LE 2 Guanaco densities by biozone in the southern Patagonian provinces of Chubut and Santa Cruz (Argentina) reported by Bay Gavuzzo et al. (2015) and Manero et al. (2013). Central District was divided into abandoned $\left(102,764 \mathrm{~km}^{2}\right.$ in Santa $\mathrm{Cruz}^{2}$ and $29,297 \mathrm{~km}^{2}$ in Chubut) and productive (the remaining area), following the criteria of Marino et al. (2020)

\begin{tabular}{|c|c|c|c|c|c|}
\hline & \multicolumn{3}{|c|}{ Santa Cruz } & \multicolumn{2}{|l|}{ Chubut } \\
\hline & $\mathrm{km}^{2}$ & Guanacos $/ \mathrm{km}^{2}$ & Guanacos $/ \mathrm{km}^{2}$ & $\frac{\text { Area }}{\mathrm{km}^{2}}$ & Guanacos $/ \mathrm{km}^{2}$ \\
\hline Central district productive & 29,243 & 6.62 & 3.96 & 58,184 & 2.31 \\
\hline Mulguraea shrubland & 28,299 & 7.44 & 6.2 & 0 & $\mathrm{n} / \mathrm{d}$ \\
\hline Subandean grasslands & 19,531 & 8.1 & 4.9 & 16,445 & 0 \\
\hline West plateaus & 13,150 & 6.59 & 4.84 & 54,114 & 5.86 \\
\hline Austral Monte & 0 & $n / d$ & $\mathrm{n} / \mathrm{d}$ & 37,049 & 5.06 \\
\hline Abandoned area & 102,764 & 6.62 & 3.96 & 29,297 & 2.31 \\
\hline Productive area & 119,873 & 7.19 & 4.63 & 179,913 & 4.82 \\
\hline Total & 222,637 & & & 209,210 & \\
\hline
\end{tabular}

Magellan Steppe biozones in Santa Cruz, we used those reported by Manero, Dragnic, Clifton, and Vargas (2013) and multiplied them by the average increase in the guanaco population between 2013 and 2015; this resulted in an estimate of 10.9 guanacos $/ \mathrm{km}^{2}$ in the Dry Magellanic Steppe, and 4.8 guanacos $/ \mathrm{km}^{2}$ in the Humid Magellanic Steppe. Once all biozones had an estimated guanaco population, we considered the Central District as the area without domestic grazing, and all the other biozones as areas with domestic grazing. Taking into account this additional grazing effect by guanacos, overgrazing in the area with livestock in Santa Cruz increases to $106 \%$, and to $49 \%$ in Chubut (Table 1 ).

In retrospect, conclusions in Oliva et al. (2019) may have conveyed the idea that no further adjustment in domestic stock numbers was necessary and that the main control should be on growing guanaco 
populations. This is not so, but the fact that domestic grazing numbers, together with growing guanaco populations, exceed carrying capacity in still-productive sheep land only stresses the point that urgent joint management of a native-domestic herbivore system is required. Local management plans give an opportunity to do so, as the Provincial Guanaco Management Plan for Santa Cruz Province specifies that permits should only be issued in areas that are not overgrazed by sheep.

\section{3 | ESTIMATION OF CARRYING CAPACITY FOR MIXED GRAZING SYSTEMS}

Marino et al. (2020) claim that regional carrying capacity estimations of the Oliva et al. (2019) analysis are unrealistic because they provide estimates for different species based on the assumption of 'each herbivore having exclusive use of the land'. We suggest that this is based on a misinterpretation of our approach, as it is clear that different domestic and native herbivore species share the land. There are infinite ways of combining sheep, goats, bovines and guanacos to comply with a given total herbivore carrying capacity. In Oliva et al. (2019), we simply converted the regional carrying capacity into numbers of herbivores for each species and expressed the estimated carrying capacity as if it were the only species consuming the plant biomass. It is true that linear combinations of herbivores are oversimplifications and that the apparent overabundance of ungulates on Patagonian rangelands might be mitigated by resource partitioning. Sheep and guanaco diets are similar but camelids show better mixing, maceration and buffering of digesta (Vallenas, Cummings, \& Munnell, 1971) so that overlap analysis may show that joint domesticguanaco systems would achieve a better use of primary productivity by diversifying consumption (San Martin \& Bryant, 1989) and landscape use (Pedrana et al., 2019). This would reduce the impact of a given ungulate biomass on the rangelands but, unfortunately, modelling this overlap would require information on vegetation types, seasonal variations, state of rangelands in relation to management, and distribution in the landscape, an endeavour almost impossible at a regional scale. Any analysis conducted at a scale that covers Patagonia requires simplifications and assumptions, but is still useful for generating testable hypotheses that are important for ongoing management at more local scales.

\section{4 | GUANACO DISTRIBUTION IN RELATION TO DOMESTIC GRAZERS}

Marino et al. (2020) argue that, following the massive expansion of sheep farming in Patagonia, 'Remaining guanacos persisted in marginal habitats or protected areas' and claim that data showing exclusion of

TA B LE 3 Area (ha), guanaco and sheep density (Individuals and Animal Units $/ \mathrm{km}^{2}$ ), combined sheep + guanaco density (Animal Units/ $\mathrm{km}^{2}$ ), carrying capacity based on MOD17/A3 images $\left(\mathrm{AU} / \mathrm{km}^{2}\right)$ and overgrazing ((stocking rate - carrying capacity)/carrying capacity $\left.\times 100\right)$ for 13 sheep and cattle stations in Santa Cruz province totalling 434,812 ha (Cepeda et al., 2019). Original guanaco density data in (Oliva et al., 2020)

\begin{tabular}{|c|c|c|c|c|c|c|c|c|c|c|}
\hline \multirow[b]{3}{*}{ Farm } & \multirow{3}{*}{$\begin{array}{l}\text { Area } \\
\text { ha }\end{array}$} & \multicolumn{2}{|c|}{ Guanaco } & \multicolumn{2}{|c|}{ Sheep } & \multirow{3}{*}{$\begin{array}{l}\begin{array}{l}\text { Guanaco + } \\
\text { sheep }\end{array} \\
\mathrm{AU} \\
\mathrm{km}^{2}\end{array}$} & \multirow{3}{*}{$\begin{array}{l}\begin{array}{l}\text { Carrying } \\
\text { capacity }\end{array} \\
\mathrm{AU} \\
\mathrm{km}^{2}\end{array}$} & \multirow{3}{*}{$\begin{array}{l}\text { Overall } \\
\text { grazing } \\
\text { status } \\
(\%)\end{array}$} & \multirow{3}{*}{$\begin{array}{l}\text { Guanaco } \\
\text { only over } \\
\text { grazing } \\
(\%)\end{array}$} & \multirow{3}{*}{$\begin{array}{l}\text { Sheep } \\
\text { only over } \\
\text { grazing } \\
\text { (\%) }\end{array}$} \\
\hline & & \multirow{2}{*}{$\frac{\text { Ind }}{\mathrm{km}^{2}}$} & \multirow{2}{*}{$\frac{\mathrm{AU}}{\mathrm{km}^{2}}$} & \multirow{2}{*}{$\frac{\text { Ind }}{\mathrm{km}^{2}}$} & \multirow{2}{*}{$\frac{\mathrm{AU}}{\mathrm{km}^{2}}$} & & & & & \\
\hline & & & & & & & & & & \\
\hline Bella Vista & 42,994 & 32 & 7.5 & 35 & 5.4 & 12.9 & 6.4 & 100.8 & 16.4 & -15.6 \\
\hline Cerro Bombero & 17,982 & 18 & 4.2 & 9 & 1.5 & 5.7 & 1.9 & 204.1 & 126.2 & -22.1 \\
\hline Chank Aike & 30,099 & 16 & 3.8 & 17 & 2.7 & 6.5 & 3.9 & 64.7 & -4.5 & -30.8 \\
\hline Coy Aike & 16,100 & 30 & 7.0 & 26 & 4.0 & 11.1 & 4.1 & 168.5 & 70.4 & -1.9 \\
\hline La Argentina & 21,873 & 47 & 11.0 & 18 & 2.8 & 13.8 & 5.9 & 131.8 & 85.3 & -53.5 \\
\hline Los Machos & 31,100 & 20 & 4.7 & 0 & 0.0 & 4.7 & 2.4 & 93.9 & 93.9 & \\
\hline Makenke & 87,655 & 12 & 2.8 & 24 & 3.8 & 6.6 & 3.7 & 77.6 & -23.9 & 1.5 \\
\hline Miramar & 33,780 & 24 & 5.5 & 15 & 2.3 & 7.8 & 2.8 & 179.6 & 98.1 & -18.5 \\
\hline Weighted mean & 33,447 & 26 & 6.0 & 18 & 2.8 & 8.8 & 4.0 & 126.4 & 56.0 & -22.4 \\
\hline \multirow[t]{4}{*}{$S E$} & 5,464 & 3.8 & 0.9 & 2.5 & 0.4 & 1.0 & 0.4 & 23.1 & 19.0 & 8.5 \\
\hline & & & & & & \multicolumn{2}{|c|}{$\#$ of overgrazing cases $\rightarrow$} & 12.0 & 10.0 & 1.0 \\
\hline & & & & & & \multicolumn{2}{|c|}{$\#$ of undergrazing cases $\rightarrow$} & 1.0 & 3.0 & 12.0 \\
\hline & & & & & & \multicolumn{2}{|c|}{$\%$ of overgrazing cases $\rightarrow$} & 92.3 & 76.9 & 7.7 \\
\hline
\end{tabular}


guanacos from areas dominated by livestock 'consistent across different spatial scales, support the hypothesis that guanacos can only occupy areas where they are able to exploit forage that is out of reach of livestock'. Marino et al. (2020) also mention 'ecological release (Begon, Townsend, \& Harper, 2006) of guanacos after sheep removal has been documented, confirming competitive exclusion by a process-oriented approach (Burgi, Marino, Rodríguez, Pazos, \& Baldi, 2012)'. We are not aware of literature that demonstrates unequivocally that competitive exclusion exists between sheep and guanacos. On the contrary, references (Baldi, Albon, \& Elston, 2001; Pedrana, Bustamante, Travaini, \& Rodríguez, 2010) used by Marino et al. (2020) leave open alternative explanations to competitive exclusion, including a direct influence of human presence, as guanacos tend to occur where human pressure is lower because of poaching and general productive activity. Marino et al. (2020) also claim that guanacos can only occupy areas where they are able to exploit forage that is out of reach of livestock, and cite as an example the southern grasslands of Peninsula Valdés. We believe that this case cannot be generalised; guanaco populations are found in productive areas of Patagonia with sheep (Hernández et al., 2017; Karesh et al., 1998) suggesting that they can coexist. In fact, if competitive exclusion was commonplace, the current perception of sheep ranchers of guanaco as livestock competitors would not have arisen. Between 2016 and 2018, Cepeda et al. (2019) estimated guanaco population density using 361 terrestrial transects from 0.8 to $10 \mathrm{~km}$ in length, totalling $323 \mathrm{~km}$ in 13 farms in Santa Cruz province, with a total area of $4,740 \mathrm{~km}^{2}$. They used this as an input for guanaco farm management plans required by the authorities of Santa Cruz province. The data, available in a Dryad Database (Oliva, Paredes, Ferrante, Cepeda, \& Rabinovich, 2020), were analysed using Distance Sampling 7.0 (Buckland, Anderson, Burnham, \& Laake, 2005) software, stratified by date, and using global density with a half-normal detectability function and cosine expansion series to estimate density (Table 3). Sheep and guanaco numbers were compared to the MOD17/A3 herbivore carrying capacity as presented in Oliva et al. (2019; Table 3). These active farms show high densities of guanaco in interaction with sheep, and in all but one of the farms, guanaco grazing pressure in Animal Units (that compensate for mass differences between the herbivore species) was higher than the one generated by sheep. When looking at each herbivore species separately, the guanaco population is on average $56 \%$ above the carrying capacity, whereas sheep stock is $22 \%$ below. Combined grazing pressures were well over the grazing capacity in all but one farm, with an estimated average overgrazing of 126\%. Under these conditions, both guanacos and sheep would remain chronically underfed, and forced to consume low-quality forage that may compromise their nutrient balance with low production and fertility indexes and increased mortality risk during climatic emergencies.

\section{5 | POPULATION REGULATION AND GUANACO OVERGRAZING RISK}

Marino et al. (2020) claim that guanaco populations are regulated by a bottom-up process of resource-defence territoriality that would keep them from overshooting carrying capacity and degrading the land. Although this theoretical mechanism is plausible, the data in Table 3 show that, in places in southern Patagonia where guanacos can disperse relatively freely, their populations can exceed the estimated carrying capacity of the land independently of whatever may be the true population regulation mechanism in place. Additionally, there is a well-documented case of a guanaco population crash in Cabo dos Bahías, a protected area in Chubut. By 1995, guanaco populations in that area had increased to almost 42 guanacos $/ \mathrm{km}^{2}$ (Karesh et al., 1998) even with sheep grazing; in 2000, 60\% of the population died, probably from starvation (Beldomenico et al., 2003). Marino, Pascual, and Baldi (2014) themselves monitored population growth rates thereafter and mention that, following the 2000 high mortality event, guanaco density recovered rapidly. Recruitment rates of over 0.40 newborns female ${ }^{-1}$ year $^{-1}$ were registered in six out of 8 years from 2001 to 2008, when densities estimated using the MOD17A3 methodology were already over the carrying capacity of $34 \pm 6$ guanacos $/ \mathrm{km}^{2}$. Even with these high fecundity values, Marino et al. (2014) point out that 'recruitment alone was not high enough to generate the observed recovery and, therefore, strong immigration must have taken place during the study period in order to make the observed population growth rate possible'. As densities close to 75 guanacos $/ \mathrm{km}^{2}$ were reported by the end of this study, we fitted an exponential model to the guanaco population data of fig. 4 of Marino et al. (2014), and obtained a highly statistically significant fit $\left(y=-590.4 \exp (0.2962 \times t)\right.$; adjusted $R^{2}=0.9828 ; p$ value $=0.00063$ ), confirming our argument that a density-dependent reduction in population growth rate was not evident from the time period analysed. Thus, although resource-based territoriality is a plausible mechanism of guanaco population regulation, it does not seem to have operated in this place and in this period. Resource overexploitation and a second population crash could be expected with these population densities well above the estimated carrying capacity.

\section{I CONSERVATION AND MANAGEMENT IMPLICATIONS}

We believe that the subject of guanaco conservation and management as framed by Marino et al. (2020) only reflects the nature preservation sector of the stakeholders around the guanaco-domestic stock conflict. That perspective underpins their claim that 'Massive economic and political efforts are underway by the Santa Cruz Provincial and National governments to change current legislation and allow the reduction of guanaco numbers, instead of fostering the improvement of livestock management schemes'. It is true that some resources have been mobilised, and several institutions have joined efforts to develop a much-needed guanaco provincial management plan, as well as the option of commercial hunting under specific protocols in the 2019 Guanaco National Management Plan. The guanaco management plan of Santa Cruz province was never designed as a means to only reduce guanaco 
numbers; on the contrary, permissions for sport hunting are extremely limited, a strong emphasis is given to the shearing of live guanacos to obtain commercial profits from its wool and, when commercial hunting is allowed, it is always to be conducted in a sustainable manner, and also oriented to make use of products like meat and hides that could provide value to wild guanacos in sheep stations.

Marino et al. (2020) claim that commercial management of guanacos as part of the integrated management of sheep and guanacos, as proposed by Oliva et al. (2019), is not a sustainable approach to management. Their conclusions are based upon the consequences of commercial hunting during the past century, and the concern that current extractive plans are oriented to reduce guanaco numbers in the context of weak institutions that would not be able to control illegal harvest, and this would open the door for an overexploitation of guanaco populations. Although, undoubtedly, the best of plans may go awry, during the last 4 years (2015-2019) the first serious attempts to solve the rancher-guanaco conflict under a win-win approach have been carried out. Guanaco management plans in the Santa Cruz provincial legislation, grounded on a sustainable basis and presented individually by each farm, do not constitute an extractive plan oriented to reduce guanaco numbers rapidly, as Marino et al. (2020) feared. These plans are based on direct, annual field evaluations of grasslands' carrying capacity, and guanaco and sheep densities, and not all permits are for extraction quotas, as some farms have carried out live shearing to market guanaco wool, showing their confidence in the guanacos as an economically useful natural resource instead of a sheep competitor. When extraction permits are required, the provincial management plan specifically states that the quotas for extraction can be only authorised once the domestic stock is adjusted so that guanaco management is oriented to adjust domestic and native herbivore stock to the carrying capacity. Quotas are estimated yearly based on the application of a matrix population model that promotes the sustainable management of guanaco populations (Rabinovich, 2017). This management model, applied to the 13 farms with the data provided in Table 3 , generated an average guanaco off take quota of $18.6 \%$ of the adult and juvenile population, with a minimum of $12.8 \%$ and a maximum of $27.5 \%$. To obtain permits, these producers would have to regulate their stocks and, in this way, guanaco management plans provide an orderly mechanism to regulate herbivores (wild and domestic), forcing ranchers to evaluate and take into account the carrying capacity of the land.

Our large-scale analysis of the Patagonian rangelands cannot address specific management options, which are only possible at a local scale. Despite that, we believe that, thanks to the arguments elicited by the Marino et al. (2020) paper, a testable hypothesis emerges from our conclusions: that direct competition for forage as well as human activity results in spatial segregation between sheep and guanacos; this hypothesis could be tested on two grounds: (a) by scientific research based upon an appropriate field experimental design and (b) using the information of the current guanaco management plan being carried out in Santa Cruz; these approaches would complement each other in their results and should be able to determine if only the direct competition for forage or only the human activity (or an interaction between both) are the factors responsible for the segregation between guanacos and sheep when it happens, as well as the possible reasons for those cases with a lack of segregation (that we have documented above).

Whatever mechanisms maintained the integrity of guanaco-grazed rangelands prior to human colonisation, there is no doubt that sheep introductions, together with artificial water holes, fences and more than a century of continuous grazing with fixed, high stocking rates, have profoundly degraded the vegetation, with loss of topsoil and perennial plant cover. This process is part of the worldwide modification of the Anthropocene (Lewis \& Maslin, 2015) that makes it impossible to restore original conditions that were supposed to be at equilibrium. Faced with a sharp increase in grazing pressure from guanacos and livestock, we are currently forced to manage the Patagonian land to preserve it, including an improvement of livestock management schemes, as Marino et al. (2020) request, but also through the sustainable management of native herbivores such as the guanaco. To postpone management of native herbivores based on weak institutional and technical expertise at this stage would only induce poaching and illegal culling, and block the early commercial development of guanaco products that can transform an apparent competitor into a valuable natural resource, complementary to sheep raising.

\section{ACKNOWLEDGEMENTS}

Guanaco data collection was funded by project PE INTA 'Evaluación, monitoreo y manejo de la biodiversidad en sistemas agropecuarios y forestales 2019-PD-E2-1038-002'.

\section{AUTHORS' CONTRIBUTIONS}

G.O. and J.R. led the writing of this response manuscript; P.P. re-calculated carrying capacities at a biozone $x$ province scale; C.C. collected and analysed ground data from farm scale guanaco populations included as new evidence; D.F. analysed critically the possible responses. All authors contributed with correction to the drafts and gave final approval for publication.

\section{DATA AVAILABILITY STATEMENT}

Data of guanaco density based on terrestrial surveys of 13 farms in South Patagonia included in Table 3 are available via the Dryad Database https://doi.org/10.5061/dryad.fxpnvxOnw (Oliva et al., 2020). Each row of the annexed.xIs table represents a guanaco group spotted and includes the variables: Farm (name); Farm area $\left(\mathrm{km}^{2}\right)$; Date of survey; Transect no; Length of transect $(\mathrm{km})$; Latitude and Longitude in degrees, minutes, seconds (Datum WGS84); Latitude $(X)$ and Longitude $(Y)$ in Transverse Mercator coordinates (Central meridian -69, False northing 10,001,965.73 m) of the vehicle position, Azimuth of the road (angle of deviation of the road direction in degrees, where north $=0$ ); Angle (deviation of the guanaco group in relation to the main road direction in degrees); Distance to the guanaco group (measured by laser distanciometer, meters), Number 
of guanacos, Category (Adult, Juvenile or Undetermined). Cadastral outlines of these farms, tracks of guanaco survey transects and position of the guanaco groups including number and category are shown in the .klm file of Appendix II.

\section{ORCID}

Gabriel Oliva (iD https://orcid.org/0000-0002-7839-8851

Jorge Rabinovich iD https://orcid.org/0000-0002-3792-742X

\section{REFERENCES}

Baldi, R., Albon, S. D., \& Elston, D. A. (2001). Guanacos and sheep: Evidence for continuing competition in arid Patagonia. Oecologia, 129, 561-570. https://doi.org/10.1007/s004420100770

Baldi, R., de Lamo, D., Failla, B. M., Ferrando, P., Nugent, P., Puig, S., \& Rivera, S. (2006). Plan nacional de manejo del guanaco (Lama guanicoe). Buenos Aires, Argentina: SADyS- Secretaria de Ambiente y Desarrollo Sostenible de la Nación.

Bay Gavuzzo, A., Gaspero, P., Bernardos, J., Pedrana, J., de Lamo, D. \& Von Thungen, J. (2015). Distribución y densidad de guanacos (Lama guanicoe) en la Patagonia. Informe de relevamiento 2014-2015. Bariloche, Argentina: Ediciones INTA.

Begon, M., Townsend, C. R., \& Harper, J. L. (2006). Ecology: From individuals to ecosystems. Oxford, UK: Blackwell Publishing.

Beldomenico, P., Uhart, M., Bono, M., Marull, C., Baldi, R., \& Peralta, J. (2003). Internal parasites of free-ranging guanacos from Patagonia. Veterinary Parasitology, 118, 71-77. https://doi.org/10.1016/j.vetpar. 2003.09.008

Buckland, S. T., Anderson, D. R., Burnham, K. P., \& Laake, J. L. (2005). Distance sampling. Encyclopedia of Biostatistics, 2. https://doi.org/ 10.1002/0470011815.b2a16019

Burgi, M. V., Marino, A., Rodríguez, M. V., Pazos, G., \& Baldi, R. (2012). Response of guanacos Lama guanicoe to changes in land management in Península Valdés, Argentine Patagonia: Conservation implications. Oryx, 46, 99-105.

Cepeda, C., Torres, V., Vivar, E., Paredes, P., Ferrante, D., Gallardo, R., \& Oliva, G. (2019). Informe Integrador Relevamientos de poblaciones de guanacos de Santa Cruz para prueba Piloto nacional. Río Gallegos, Argentina: INTA EEA Santa Cruz.

Hernández, F., Corcorán, D., Graells, G., Roos, C., \& Downey, M. (2017). Rancher perspectives of a livestock-wildlife conflict in Southern Chile. Rangelands, 39, 56-63. https://doi.org/10.1016/j.rala.2017.02.002

Karesh, W., Uhart, M., Dierenfeld, E., Braselton, W., Torres, A., House, C., ... Cook, R. (1998). Health evaluation of free-ranging guanaco (Lama guanicoe). Journal of Zoo and Wildlife Medicine: Official Publication of the American Association of Zoo Veterinarians, 29, 134.

Lewis, S. L., \& Maslin, M. A. (2015). Defining the anthropocene. Nature, 519, 171-180. https://doi.org/10.1038/nature14258
Manero, A., Dragnic, K., Clifton, G., \& Vargas, P. (2013). Relevamiento de poblaciones de guanaco en la provincia de Santa Cruz. Rio Gallegos, Argentina: UNPA Universidad Nacional de la Patagonia Austral, Unidad Académica Rio Gallegos.

Marino, A., Pascual, M., \& Baldi, R. (2014). Ecological drivers of guanaco recruitment: Variable carrying capacity and density dependence. Oecologia, 175, 1189-1200. https://doi.org/10.1007/s0044 2-014-2965-z

Marino, A., Rodriguez, M., \& Schroeder, N. (2020). Wild guanacos as scapegoat for continued overgrazing by livestock across southern Patagonia. Journal of Applied Ecology, 1-6. https://doi.org/10.1111/ 1365-2664.13536

Oliva, G., Paredes, P., Ferrante, D., Cepeda, C., \& Rabinovich, J. (2019). Remotely sensed primary productivity shows that domestic and native herbivores combined are overgrazing Patagonia. Journal of Applied Ecology, 56, 1575-1584. https://doi.org/10.1111/1365-2664.13408

Oliva, G., Paredes, P., Ferrante, D., Cepeda, C., \& Rabinovich, J. (2020). Data from: Guanaco observations in South Patagonia. Dryad Digital Repository, https://doi.org/10.5061/dryad.fxpnvxOnw

Pedrana, J., Bustamante, J., Travaini, A., \& Rodríguez, A. (2010). Factors influencing guanaco distribution in southern Argentine Patagonia and implications for its sustainable use. Biodiversity and Conservation, 19, 3499-3512. https://doi.org/10.1007/s10531-010-9910-1

Pedrana, J., Travaini, A., Zanón, J. I., Zapata, S. C., Rodríguez, A., \& Bustamante, J. (2019). Environmental factors influencing guanaco distribution and abundance in central Patagonia, Argentina. Wildlife Research, 46, 1-11. https://doi.org/10.1071/WR18085

Rabinovich, J. (2017). Modelo de Manejo de Guanacos Silvestres en la Provincia de Santa Cruz. Informe Final de consultoría. La Plata, Argentina: SEPYME (Secretaría de Emprendedores y de la Pequeña y Mediana Empresa, Ministerio de la Producción de la Nación, Argentina).

San Martin, F., \& Bryant, F. C. (1989). Nutrition of domesticated South American Ilamas and alpacas. Small Ruminant Research, 2, 191-216. https://doi.org/10.1016/0921-4488(89)90001-1

SAyDS. (2019). Plan Nacional para el Manejo Sostenible del Guanaco. Resolución 243/19. Buenos Aires, Argentina: Secretaría de Gobierno de Ambiente y Desarrollo Sustentable.

Vallenas, A., Cummings, J., \& Munnell, J. (1971). A gross study of the compartmentalized stomach of two new-world camelids, the llama and guanaco. Journal of Morphology, 134, 399-423. https://doi. org/10.1002/jmor.1051340403

How to cite this article: Oliva G, Paredes P, Ferrante D, Cepeda C, Rabinovich J. Are Patagonia grasslands being overgrazed? A response to Marino et al. (2020). J Appl Ecol. 2020;00:1-7. https://doi.org/10.1111/1365-2664.13753 